\title{
Adsorption of Cadmium, Manganese and Lead Ions from Aqueous Solutions Using Spent Coffee Grounds and Biochar Produced by Its Pyrolysis in the Fluidized Bed Reactor
}

\author{
Jarosław Chwastowski * ${ }^{(}$, Dariusz Bradło $@$ and Witold Żukowski $\odot$ \\ Department of Inorganic Chemistry and Technology, Cracow University of Technology, Warszawska 24, \\ 31-155 Cracow, Poland; dariusz.bradlo@pk.edu.pl (D.B.); witold.zukowski@pk.edu.pl (W.Ż.) \\ * Correspondence: jaroslaw.chwastowski@pk.edu.pl
}

Received: 11 May 2020; Accepted: 17 June 2020; Published: 20 June 2020

\begin{abstract}
The adsorption process of cadmium ions $(\mathrm{Cd})$, manganese ions $(\mathrm{Mn})$ and lead ions $(\mathrm{Pb})$ onto the spent coffee grounds (SCG) and activated spent coffee grounds (biochar, A-SCG) was investigated. The SCG activation was carried out in the pyrolysis process in a fluidized bed reactor. scanning electron microscope (SEM) with energy dispersive X-ray spectroscopy (EDX), Fourier-transform infrared spectroscopy (FTIR), Brunauer-Emmett-Teller (BET) measurements and CHN analysis were used in order to define the differences between biomaterials. In the study the different mass of materials $(0.2-0.5 \mathrm{~g})$ and constant heavy metal volume and concentration $(20 \mathrm{~cm} 3 / 100 \mathrm{ppm})$ were investigated on the adsorption process. In order to describe the sorption parameters the Langmuir, Freundlich and Temkin isotherms were used. The maximum adsorption for biochar reached $22.3 \mathrm{mg} / \mathrm{g}$ for $\mathrm{Pb}$ ions, $19.6 \mathrm{mg} / \mathrm{g}$ for $\mathrm{Mn}$ ions and $19.4 \mathrm{mg} / \mathrm{g}$ for $\mathrm{Cd}$ ions which were noticeably higher than the results obtained for spent coffee grounds which reached $13.6 \mathrm{mg} / \mathrm{g}$ for Pb ions, $13.0 \mathrm{mg} / \mathrm{g}$ for $\mathrm{Mn}$ ions and $11.0 \mathrm{mg} / \mathrm{g}$ for Cd ions. Metal ion adsorption on both SCG and A-SCG was best described by the Langmuir model, thus chemisorption was a dominant type of adsorption. Studying the kinetics of the sorption process, one can see that the process is of a chemical nature according to the best fit of the pseudo-second rate order model. The obtained results show that the chosen sorbents can be used for the removal of cadmium, manganese and lead compounds from aqueous solutions with high efficiency.
\end{abstract}

Keywords: adsorption; cadmium; manganese; lead; biosorbents

\section{Introduction}

Increasing knowledge about heavy metal toxicity and legal requirements for industrial emissions reduction has led scientists to intensify $R \& D$ activity in the area of wastewater treatment [1]. Various aqueous solutions of heavy metal ions are used in industries such as metal processing, electroplating, tanning, etc. Accumulation of toxic compounds in various organisms has brought about the point where water remediation processes are extremely important. Biosorption is a cost-effective option for the removal of toxic metal compounds from aqueous solutions [2]. The use of biological materials including living and non-living organisms in the processes of removal and remediation of toxic metals has gained crucial credibility in recent years due to their good performance, ease of use and universal access [3].

Cadmium is a highly toxic metal that can cause lethal damage to various parts of the human body the bones and kidneys. It can cause erythrocyte destruction, diarrhea, nausea, salivation, muscular cramps, renal degradation and chronic pulmonary problems. The major industries that releases 
cadmium compounds into the environment are in the manufacturing of alloys, batteries, pigments and plastics. The WHO (World Health Organization) and AWWA (American Water Works Association) recommends that the drinking water should not exceed $0.005 \mathrm{mg} / \mathrm{dm}^{3}$ of Cd(II) [4].

Manganese can cause organoleptic and operating problems when present in groundwater. It can consume chlorine in the disinfection process and promote biofouling and corrosion in water networks caused by microorganisms [5]. Nowadays, there are various methods to remove Mn such as initial aeration followed by rapid filtration, $\mathrm{pH}$ adjustment and secondary rapid filtration or biofiltration with the use of manganese oxidizing bacteria that colonize the sorption bed. In nature the bacteria present in raw waters are able to proliferate in the sand filters under the optimal conditions and are able to oxidize the divalent manganese $\mathrm{Mn}$ (II) to their oxidized form $\mathrm{Mn}(\mathrm{IV})$ [6].

Lead is a hazardous heavy metal that is present in industrial wastewater. It causes diseases like mental disorder, anorexia or even death. Lead ions can be found in the process of refining ores, metal processing, sludge disposal, production of pesticides, metallurgical engineering and oxidation $[7,8]$. The most common ways to purify wastewater are ion exchange, precipitation and sorption processes. These processes are in general expensive and ineffective, especially when the concentrations of metals are in the range between $50-100 \mathrm{mg} / \mathrm{cm}^{3}$ [9].

Recent studies have shown that biochar has been used with success in metal-polluted water treatment due to its highly specific properties like hydrophobicity, surface charge, and surface area [10-12]. Naeem et al. used raw and acid activated wheat straw biochar for the removal of Cd ions from water with sorption capacities ranging between $31.65 \mathrm{mg} / \mathrm{g}$ and $74.63 \mathrm{mg} / \mathrm{g}$ [11]. Biochar is a black solid char derived from the pyrolysis of organic waste materials in a limiting oxygen environment [13]. It can be produced from spent coffee grounds in different types of equipment (e.g., a furnace [14,15], a tubular reactor [16,17] or a screw-conveyor reactor [18]). Each of these solutions has its own drawbacks, but the common feature of all is the limited mass and energy transfer, thus the temperature gradient can be observed as well as the disrupted diffusion of gases (into and from the sample). Novelty in the process of obtaining the biochar is to omit these difficulties through the use of the thermal process organized in the fluidized bed reactor. Bok et al. [19] performed fast pyrolysis of coffee grounds in a fluidized bed reactor where the bed was sand and the temperature was constant in the range of $400-600{ }^{\circ} \mathrm{C}$. The material was dosed gradually and the flow of $\mathrm{N}_{2}$ was sufficient to ensure about $1 \mathrm{~s}$ residence time. Nevertheless, there have been no studies on the biochar produced from spent coffee grounds that consisted up to $100 \%$ by weight of the bed and the fluidization process was performed under the $\mathrm{CO}_{2}$ condition with long residence time.

The aim of this work was to study the difference between the spent coffee grounds (SCG) and activated spent coffee grounds (biochar, A-SCG) made through the thermal processing of SCG under specific conditions on its sorption properties for the removal of the three metal ions of cadmium, manganese and lead from aqueous solutions. The results of the metal sorption were evaluated through different isotherm and kinetic model studies. The practical aspect of the work is to use the waste material and turn it into high efficiency, renewable material for the removal of heavy metal ions from the wastewaters. Initial experiments, which concerned the spent coffee grounds, showed that in contact with water, it introduces organic compounds into the solution. This is clearly evidenced by a change in the color of the entire solution due to the biological nature of the raw material tested. From the point of view of wastewater treatment, this fact is unfavourable as it could lead to a situation in which the wastewater would be treated for one impurity (e.g., metal cations) and would be contaminated with other substances (e.g., organic compounds). Therefore, it was assumed that the stage of thermal transformation of the material is necessary, because if used on a larger scale, there is a risk of water pollution through sorbent decomposition processes. 


\section{Materials and Methods}

\subsection{Materials}

One hundred percent Arabica coffee used in the studies was brewed at $100{ }^{\circ} \mathrm{C}$ and then washed with distilled water three times to remove the residues created during the brewing process. As received spent coffee grounds underwent further analysis. The A-SCG was made from the same spent coffee grounds during the process of pyrolysis. First, SCG was dried in $120^{\circ} \mathrm{C}$ for $12 \mathrm{~h}$, then screened in order to obtain particles in the range of $0.2-0.4 \mathrm{~mm}$. Afterward the prepared material was again dried in $120^{\circ} \mathrm{C}$ overnight. All the chemicals used in the study were of analytical grade from Sigma-Aldrich (Steinheim, Germany). The stock solutions of Cd(II), Mn(II) and $\mathrm{Pb}(\mathrm{II})\left(100 \mathrm{mg} / \mathrm{dm}^{3}\right)$ were prepared by dissolving the appropriate amounts of cadmium sulfate(VI), manganese(II) sulfate(VI) and lead(II) nitrate(V), respectively, in $250 \mathrm{~cm}^{3}$ of demineralized water.

\subsection{Methods}

Surface analysis was done with scanning electron microscope (SEM) equipped with an energy-dispersive X-ray spectroscopy microanalyzer (EDS). Optical photographs were obtained by means of a TPL Trino stereoscopic microscope (Rhede, Germany) equipped with a DLT-Cam PRO 5 MP camera (Mińsk Mazowiecki, Poland). The elemental analysis was carried out with the use of a Perkin Elmer CHN analyzer type 2400 (Waltham, MA, USA). To specify the moisture and ash content in the samples, additional analysis was supplemented. In order to define the characteristic chemical bonds present in the sorbent, materials were subjected to Fourier transform infrared (FTIR) spectroscopy before and after the pyrolysis process. The research was performed using a Nicolet 380 Spectrometer (Thermo Fisher Scientific, Waltham, MA, USA). Surface analysis was carried out with the use of Macrometrics ASAP 2010 (Norcross, GA, USA) with a degassing station. First, the samples were dried at $110^{\circ} \mathrm{C}$ under $(\mathrm{He})$ conditions for $8 \mathrm{~h}$ and then at $100{ }^{\circ} \mathrm{C}$ in a vacuum of 0.001 Torr for $8 \mathrm{~h}$. Metal content analysis was performed using inductively coupled plasma with optical emission spectrometry (ICP-OES) in a Perkin Elmer OPTIMA 7300 DV apparatus (Waltham, MA, USA).

The pyrolysis was carried out in the laboratory fluidized bed reactor that has been described previously in detail [20]. A total of $200 \mathrm{~g}$ of SCG was used as a bed. A quartz tubular reactor with an external diameter of $100 \mathrm{~mm}$ and height of $500 \mathrm{~mm}$ was equipped with an electrical heating jacket and insulation in order to maintain the desired temperature of the bed. To ensure pyrolytic conditions, $\mathrm{CO}_{2}$ as the fluidizing medium was applied. Its flow was controlled by a TSI 40241 flowmeter (Beijing, China) and the temperature was measured by the thermocouple located $50 \mathrm{~mm}$ above the perforated distributor. Gaseous products were monitored on-line by FTIR analyzer, Gasmet DX-4000 (Vantaa, Finland). Spectra of the gases were recorded at the intervals of $5 \mathrm{~s}$, giving the information about the concentration of the major compounds $\left(\mathrm{H}_{2} \mathrm{O}, \mathrm{CO}\right)$ as well as both organic (hydrocarbons, aldehydes, alcohols, esters etc.) and inorganic (nitric oxides, sulfur dioxide, ammonia, hydrochloric acid, cyanuric acid etc.) ones. The second analyzer (Horiba PG250, Kyoto, Japan) was used for measuring $\mathrm{O}_{2}$ (by electrochemical detector) and for comparative purposes NOx (by chemiluminescence method) with $\mathrm{CO}, \mathrm{CO}_{2}$ and $\mathrm{SO}_{2}$ (by the nondispersive infrared detector, NDIR). Gaseous products of the process were transferred by the heating line $\left(180^{\circ} \mathrm{C}\right)$, however, due to intense liquid pyrolytic product condensation, an additional series of water scrubbers were used before the analytical apparatus. Thus, the concentration of $\mathrm{H}_{2} \mathrm{O}$ may be influenced by its condensation in the scrubbers (Figure 1). The pyrolysis process was performed for approximately $3 \mathrm{~h}$ and the temperature was changed gradually to ensure steady conditions with minimal turbulence and a the similar state of the bed, hence the flow of the $\mathrm{CO}_{2}$ was decreased decreasing along with rising temperature. When the temperature had reached ca. $700{ }^{\circ} \mathrm{C}$ and no hydrocarbons had been emitted (Figure 2), the process was being continued for a further $30 \mathrm{~min}$ and then stopped by turning off the heating and increasing the $\mathrm{CO}_{2}$ flow. The mass of the obtained biochar was $38.1 \mathrm{~g}$, so in the solid form retained ca. $19 \mathrm{wt} . \%$ of the SCG. 


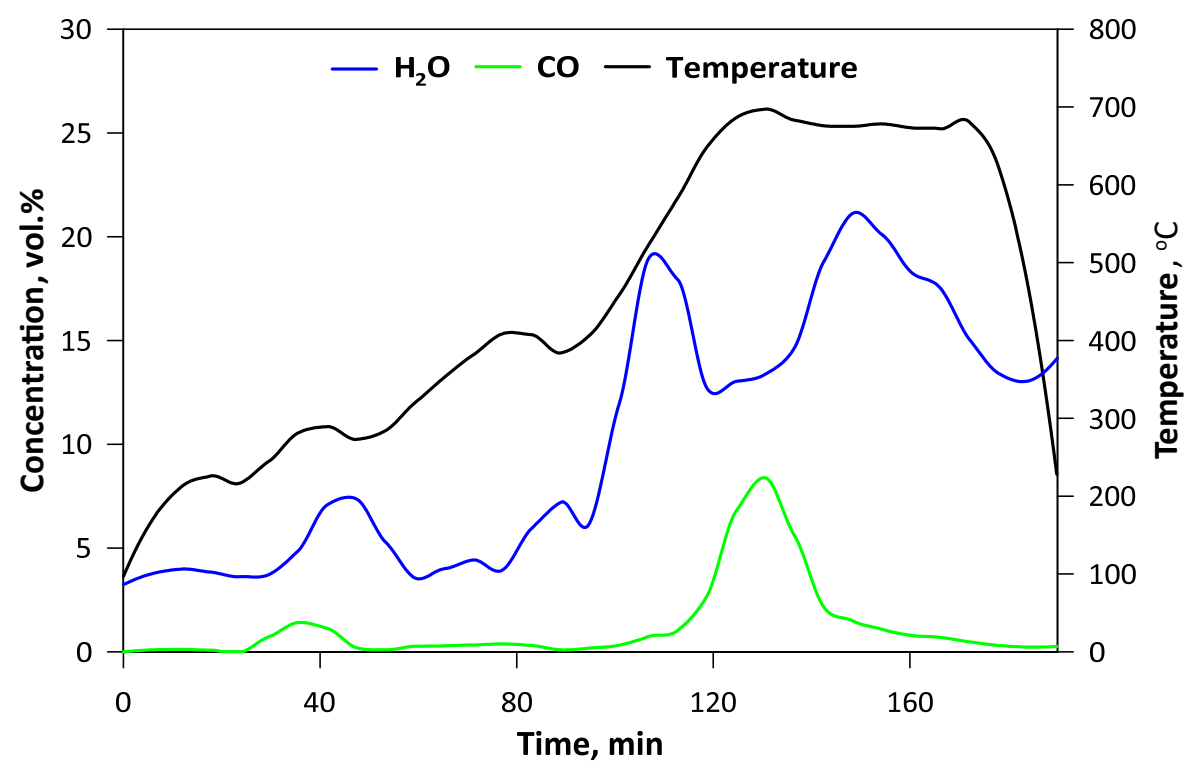

Figure 1. Temperature changes and contents of $\mathrm{H}_{2} \mathrm{O}$ and $\mathrm{CO}$ in the gaseous products during pyrolysis.

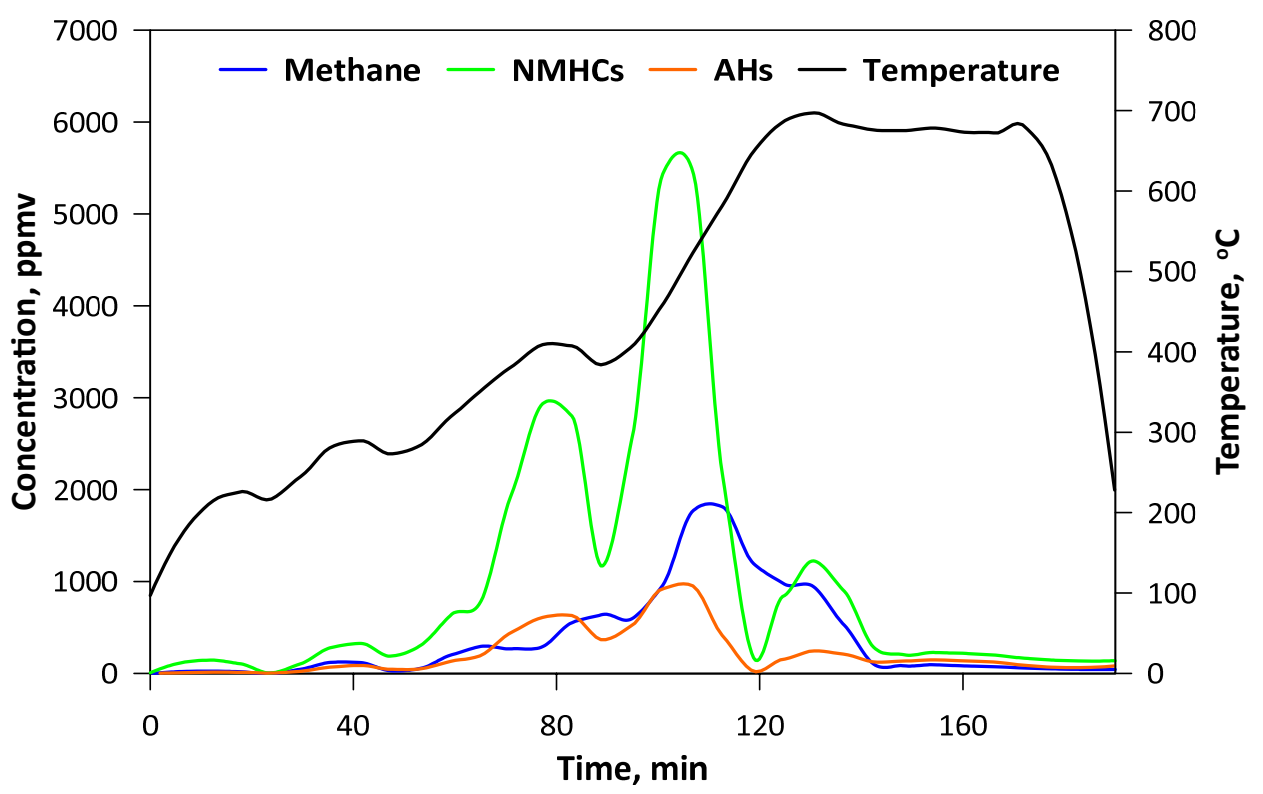

Figure 2. Concentration of hydrocarbons in the gaseous products of pyrolysis (NMHCs-nonmethane hydrocarbons; AHs-aromatic hydrocarbons).

\subsection{Adsorption Experiments}

The processes of adsorption were carried out in $60 \mathrm{~cm}^{3}$ polypropylene flasks. Different masses of SCG and A-SCG, approximately $0.02,0.05,0.10,0.20$ and $0.50 \mathrm{~g}$ were added separately and mixed with $20 \mathrm{~cm}^{3}$ of metal ion aqueous solutions with the initial concentrations ranging from $100 \mathrm{mg} / \mathrm{dm}^{3}$ to $300 \mathrm{mg} / \mathrm{dm}^{3}$ of each metal ion. Probes were then shaken at room temperature for $24 \mathrm{~h}$ on the rotary shaker at $300 \mathrm{rpm}$. The temperature of the process was equal to $25^{\circ} \mathrm{C}$ and the $\mathrm{pH}$ of the solutions was around 7 , which is the $\mathrm{pH}$ of the used material. Preliminary studies showed that changing the $\mathrm{pH}$ did not substantially change the sorption properties of the material, thus the initial $\mathrm{pH}$ was selected. Additionally the process of adjusting the $\mathrm{pH}$ would not be beneficial as the material has buffering properties.

The obtained solution was filtrated through Pureland CA $0.45 \mu \mathrm{m}$ filters and analyzed for the presence of metal ions such as $\mathrm{Cd}(\mathrm{II}), \mathrm{Mn}(\mathrm{II})$ and $\mathrm{Pb}(\mathrm{II})$, respectively. Each sorption process was 
triplicated and the obtained results were averaged. Sorption capacity at a given time $\left(\mathrm{q}_{\mathrm{t}}\right)$, at equilibrium $\left(\mathrm{q}_{\mathrm{e}}\right)$ and the percentage removal of metal ions $\left(\mathrm{R}_{\mathrm{e}}\right)$ was calculated using the equations showed below (Equations (1)-(3)) [21-23]:

$$
\begin{aligned}
\mathrm{q}_{\mathrm{e}} & =\frac{\left(\mathrm{C}_{0}-\mathrm{C}_{\mathrm{e}}\right) \cdot \mathrm{V}}{\mathrm{m} \cdot 1000} \\
\mathrm{q}_{\mathrm{t}} & =\frac{\left(\mathrm{C}_{0}-\mathrm{C}_{\mathrm{t}}\right) \cdot \mathrm{V}}{\mathrm{m} \cdot 1000} \\
\mathrm{R}_{\mathrm{e}} & =\frac{\mathrm{C}_{0}-\mathrm{C}_{\mathrm{e}}}{\mathrm{C}_{0}} \cdot 100 \%
\end{aligned}
$$

\subsection{Equilibrium Studies}

Equilibrium parameters for $\mathrm{Cd}(\mathrm{II}), \mathrm{Mn}(\mathrm{II})$ and $\mathrm{Pb}(\mathrm{II})$ ions were calculated using the Langmuir, Freundlich and Temkin isotherms (Equations (4)-(7)) [24].

The Langmuir isotherm can be presented by the linearized equation presented below:

$$
\frac{\mathrm{C}_{\mathrm{e}}}{\mathrm{q}_{\mathrm{e}}}=\frac{\mathrm{C}_{\mathrm{e}}}{\mathrm{q}_{\max }}+\frac{1}{\mathrm{~K}_{\mathrm{L}} \cdot \mathrm{q}_{\max }}
$$

The Freundlich isotherm model is represented by Equation (5):

$$
\log \mathrm{q}_{\mathrm{e}}=\log \mathrm{K}_{\mathrm{F}}+\frac{1}{\mathrm{n}} \log \mathrm{C}_{\mathrm{e}}
$$

The Temkin isotherm has a linear form, as presented by Equations (6) and (7):

$$
\begin{gathered}
\mathrm{q}_{\mathrm{e}}=\mathrm{B} \ln \mathrm{K}_{\mathrm{T}}+\mathrm{Bln}_{\mathrm{e}} \\
\mathrm{B}=\frac{\mathrm{RT}}{\mathrm{b}_{\mathrm{t}}}
\end{gathered}
$$

\subsection{Sorption Kinetics}

Studies of the adsorption kinetics were carried out to determine the time required to reach the equilibrium of the process. The sorption capacities were measured at different times for different initial concentrations. The obtained results were used for the following kinetic models:

\subsubsection{Pseudo-First Order Rate Model}

In the pseudo-first rate model, the linear equation for this model is represented by Equation (8) [25]:

$$
\ln \left(q_{e}-q_{t}\right)=\ln q_{e}-k_{1} t
$$

2.5.2. Pseudo-Second Order Rate Model

The pseudo-second order model is represented by Equation (9):

$$
\frac{t}{q_{t}}=\frac{1}{k_{2} q_{e}^{2}}+\frac{t}{q_{e}}
$$

\subsubsection{Intra Particle Diffusion Model}

The Weber-Morris model is presented by the linear equation below:

$$
\mathrm{q}_{\mathrm{t}}=\mathrm{k}_{\mathrm{id}} \mathrm{t}^{0.5}+\mathrm{I}
$$




\section{Results and Discussion}

\subsection{Characteristic of Sorbents}

Figure 3 shows the optical microphotographs ( $\times 40$ magnification $)$ and SEM microphotographs along of A-SCG and SCG samples. The organic materials used in the study had a porous and rough surface. It can be seen that the spent coffee grounds had more porous and cellular-like structure after thermal process than the unmodified one.

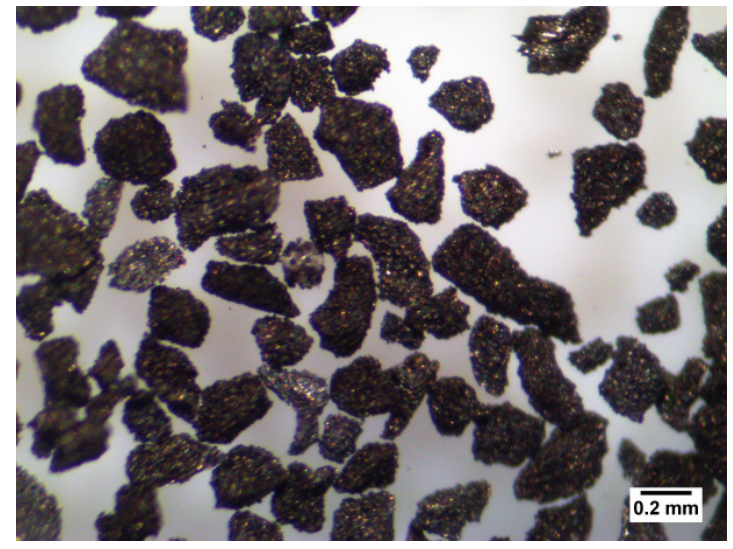

(a)

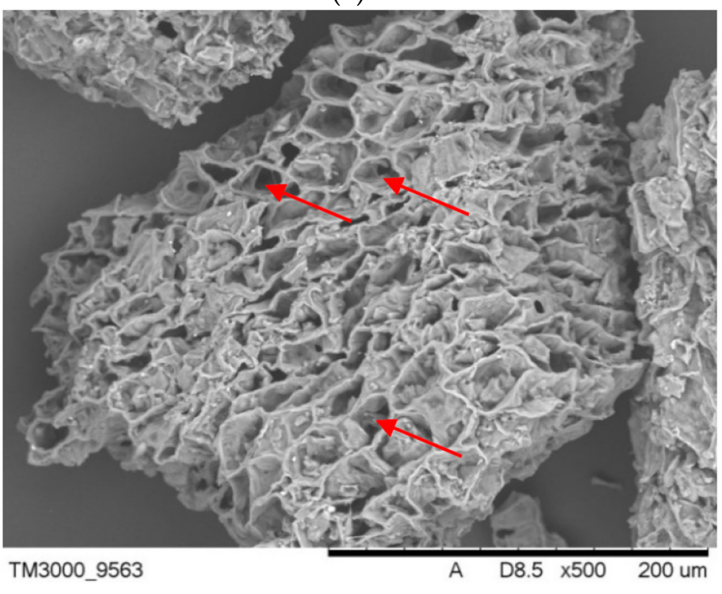

(c)

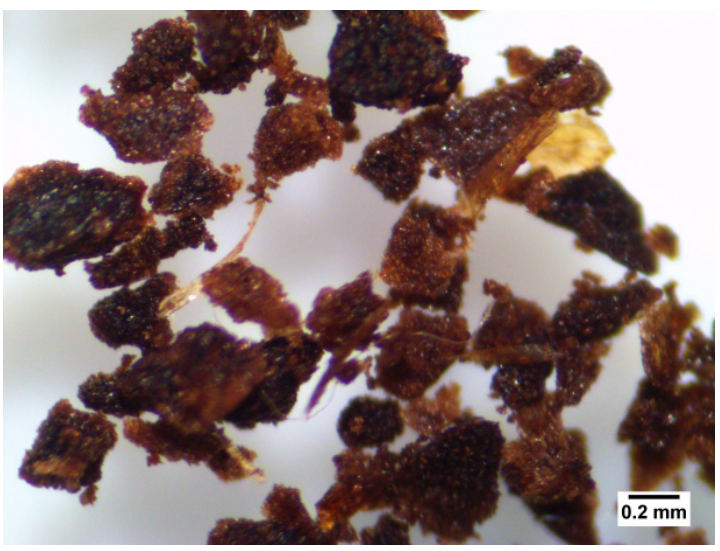

(b)

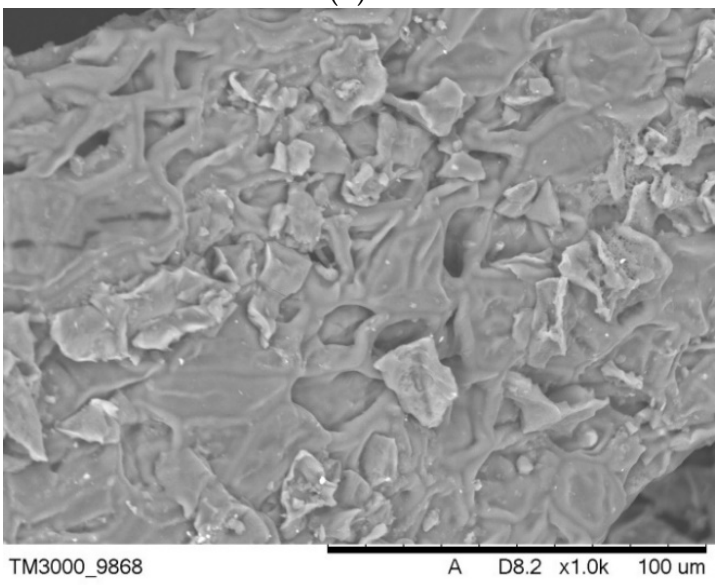

(d)

Figure 3. Optical $(\times 40)$ and SEM microphotographs of (a) A-SCG, (b) SCG; (c) A-SCG, (d) SCG. Red arrows show the caverns (increasing the sorption capacity), which occurred after the fluidization process.

According to the SEM-EDS analysis, the main elements of the tested materials were carbon and oxygen. Additionally the presence of potassium, silicone and phosphorus was found.

The $\mathrm{C} / \mathrm{H} / \mathrm{N}$ elemental analysis was determined and calculated based on the dry state of the samples. The results for A-SCG and SCG were $\mathrm{C}_{\%}=74.8 ; \mathrm{H}_{\%}=1.6 ; \mathrm{N}_{\%}=3.8 ; \mathrm{O}_{\%}=19.8$; and $\mathrm{C}_{\%}=9.3$; $\mathrm{H}_{\%}=2.3 ; \mathrm{N}_{\%}=0.8 ; \mathrm{O}_{\%}=87.6$, respectively. Pyrolysis led to significant carbonization of the material and is clearly evidenced by an increase in the mass fraction of coal and a decrease in the mass fraction of hydrogen in the sample.

BET analysis showed that A-SCG had a surface area of $6.8 \mathrm{~m}^{2} / \mathrm{g}$. Unfortunately, the surface analysis of coffee SCG was impossible to measure due to the degassing problems of the probe. According to Plaza et al. [15], high burn-off degrees of spent coffee grounds, which is equivalent to long residence time lead, to the widening of the micropores, thus obtaining a low value of surface area confirms this observation and points out that A-SCG is characterized by a microporous structure. Furthermore, Cho et al. [16] compared the pyrolysis of spent coffee grounds in both a $\mathrm{CO}_{2}$ and $\mathrm{N}_{2}$ environment and concluded that biochar from the $\mathrm{CO}_{2}$ environment exhibited higher porosity with a decreased number 
of active sites, and that this material would be favourable for retaining nutrients. The FTIR spectrum of the SCG exhibited the characteristic peaks of the cellulose structure, which were absent for A-SCG, (Figure 4). The broad peak at $3427 \mathrm{~cm}^{-1}$ is connected with the vibration of hydroxyl groups $\left(\mathrm{OH}^{-}\right)$. The peak at $1032 \mathrm{~cm}^{-1}$ shows the presence of amino groups $\left(\mathrm{NH}_{2}\right)$. The peak shown at $1622 \mathrm{~cm}^{-1}$ is consistent with the presence of carbonyl groups $\left(\mathrm{COO}^{-}\right)$, and the last peak at $2920 \mathrm{~cm}^{-1}$ corresponds to the presence of the asymmetric stretch of $\mathrm{CH}_{2}$. In the spectrum of the A-SCG, one can see that most of the characteristic peaks were lowered due to the carbonization process. This can be compared to the FTIR spectra of active carbon or graphite from the literature data [25], which shows that the pyrolysis process effectively transformed coffee into biochar.

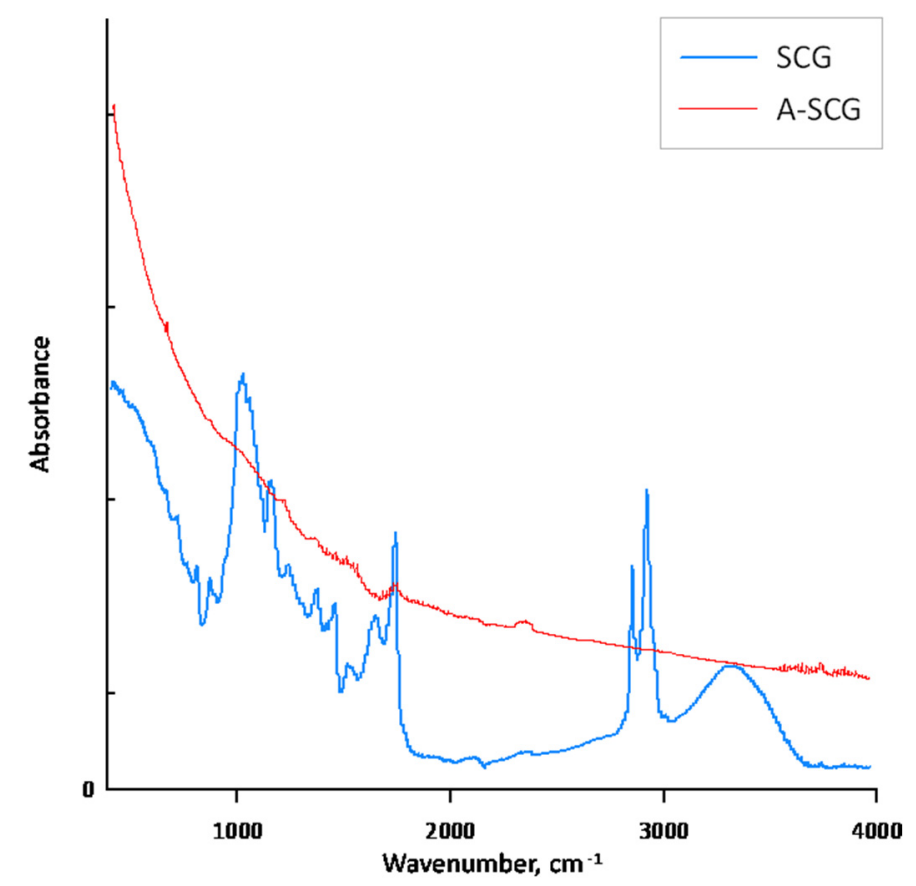

Figure 4. Fourier Transform Infrared (FTIR) spectra of used sorbent materials.

\subsection{Adsorption of $\mathrm{Cd}(\mathrm{II}), \mathrm{Pb}(\mathrm{II})$ and $\mathrm{Mn}(\mathrm{II})$ Ions in a Batch System}

The data presented in Figure 5 shows the adsorption degree of different metal ions under varying sorbent mass and constant ion concentration. Probes were shaken for $24 \mathrm{~h}$ to ensure sorption equilibrium. Additionally, in the figure shown below, one can see the sorption of $\mathrm{Cd}(\mathrm{II}), \mathrm{Pb}$ (II) and $\mathrm{Mn}$ (II) ions as a function of mass and adsorption. The changes depend on the amount and type of material used in the experiment. The differences can be explained due to the structural changes and development of the surface area between the SCG and A-SCG during the pyrolysis process. As shown in Figure 4, thermal activation caused the disappearance of IR radiation absorption for characteristic wavelengths related to the chemical composition of the untreated sorbent (saccharides, proteins, fats). This fact indicates the disappearance of functional groups, which are characterized by the presence of polar covalent bonds, which confirms the carbonization of activated material. The material is transformed in such a way that its structure begins to resemble the structure of graphite, which can be compared to the literature data [25]. Aromatization of the organic structure results in ring-delocalized orbitals (or in the form of condensed rings), which predisposes such material to form donor-acceptor bonds with metal cations. These bonds are $\pi_{\mathrm{d} \_ \text {cation-p_del_c }}$ type bonds, where electron pair acceptors are metal cations and electron pairs come from the sorbent surface. No such bonds occur without sorbent aromatization. 


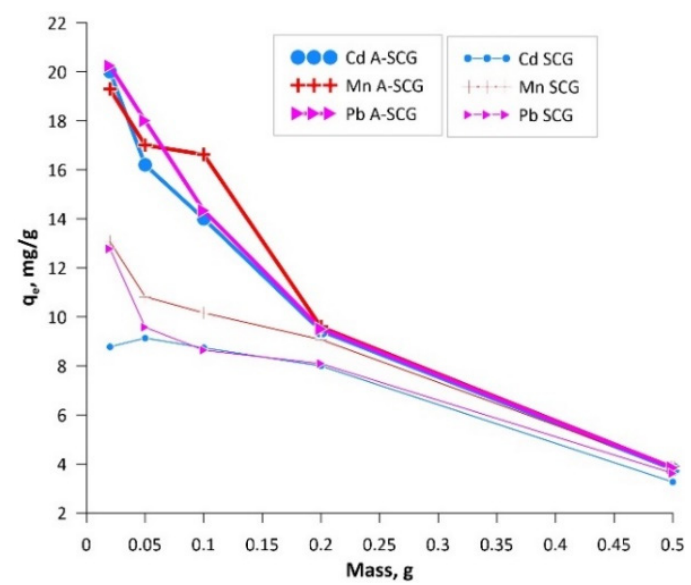

Figure 5. Graph of the adsorption of $\mathrm{Cd}(\mathrm{II}), \mathrm{Mn}(\mathrm{II})$ and $\mathrm{Pb}(\mathrm{II})$ ions at constant concentration versus mass of SCG and A-SCG.

\subsection{Equilibrium Analysis}

Sorption capacity of the used materials was determined by using the Langmuir, Freundlich and Temkin isotherms. Based on the experimental data, it can be concluded that with increasing mass ratio of adsorbent to concentration of metal ions (Cd(II), $\mathrm{Mn}(\mathrm{II}), \mathrm{Pb}(\mathrm{II})$ ), the sorption capacity decreased from $20.24 \mathrm{mg} / \mathrm{g}$ to $3.83 \mathrm{mg} / \mathrm{g}$ for A-SCG and from $12.78 \mathrm{mg} / \mathrm{g}$ to $3.62 \mathrm{mg} / \mathrm{g}$ for SCG. In addition, it can be seen that the materials could remove between 9 to $99 \%$ of ions depending on the initial mass of the materials and the ion used. Figure 6 shows the linearized forms of the studied isotherms. On their basis, the parameters of the isotherms were calculated and are summarized in Table 1.

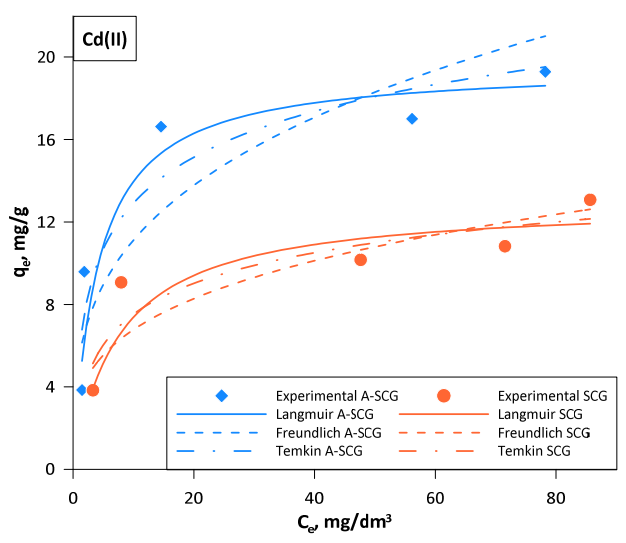

(a)

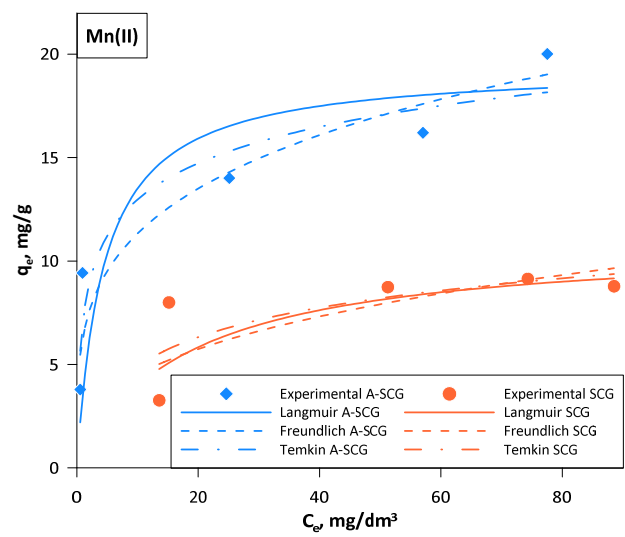

(b)

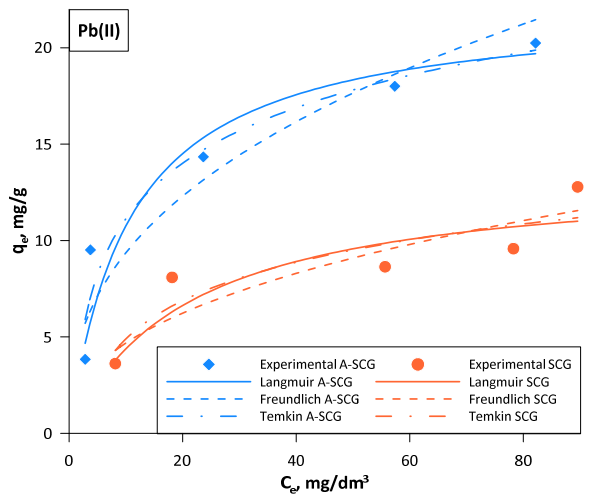

(c)

Figure 6. Langmuir, Freundlich and Temkin isotherms for A-SCG and SCG. (a) Cadmium; (b) Manganese; (c) Lead. 
Table 1. Isotherm parameters.

\begin{tabular}{|c|c|c|c|c|c|c|}
\hline & \multicolumn{2}{|c|}{$\mathrm{Cd}(\mathrm{II})$} & \multicolumn{2}{|c|}{ Mn(II) } & \multicolumn{2}{|c|}{$\mathrm{Pb}(\mathrm{II})$} \\
\hline & A-SCG & SCG & A-SCG & SCG & A-SCG & SCG \\
\hline \multicolumn{7}{|c|}{ Langmuir } \\
\hline $\mathrm{K}_{\mathrm{L}}, \mathrm{dm}^{3} / \mathrm{mg}$ & 0.2495 & 0.1318 & 0.2289 & 0.0566 & 0.0937 & 0.0477 \\
\hline $\mathrm{q}_{\max }, \mathrm{mg} / \mathrm{g}$ & 19.56 & 12.97 & 19.40 & 10.99 & 22.25 & 13.58 \\
\hline $\mathbf{R}_{\mathbf{L}}$ & 0.0392 & 0.0718 & 0.0435 & 0.1553 & 0.0961 & 0.1726 \\
\hline $\mathbf{R}^{2}$ & 0.9921 & 0.9714 & 0.9717 & 0.9200 & 0.9877 & 0.9008 \\
\hline \multicolumn{7}{|c|}{ Freundlich } \\
\hline $\mathbf{K}_{\mathrm{F}}$ & 5.448 & 3.483 & 6.329 & 2.015 & 3.785 & 1.817 \\
\hline $1 / n$ & 0.3097 & 0.2891 & 0.2529 & 0.3494 & 0.3935 & 0.4116 \\
\hline $\mathbf{R}^{2}$ & 0.7419 & 0.7778 & 0.8151 & 0.5004 & 0.8174 & 0.8227 \\
\hline \multicolumn{7}{|c|}{ Temkin } \\
\hline $\mathbf{K}_{\mathbf{T}}$ & 5.601 & 3.326 & 16.717 & 1.091 & 1.462 & 0.552 \\
\hline B & 3.209 & 2.150 & 2.534 & 2.050 & 4.151 & 2.867 \\
\hline $\mathbf{R}^{2}$ & 0.8695 & 0.8290 & 0.8970 & 0.5524 & 0.9391 & 0.8137 \\
\hline
\end{tabular}

Based on the obtained results one can see that the best model describing the sorption of the used metal ions on both A-SCG and SCG was the Langmuir isotherm model, which had the highest correlation coefficient $\mathrm{R}^{2}$ in all of the tested sets.

Constant $R_{L}$ is connected with the nature of sorption. Equation (11) was used to calculate the constant $R_{L}$ :

$$
\mathrm{R}_{\mathrm{L}}=\frac{1}{1+\mathrm{K}_{\mathrm{F}} \mathrm{C}_{0}}
$$

For $\mathrm{R}_{\mathrm{L}}$ parameters:

$\mathrm{R}_{\mathrm{L}}=0$-sorption is irreversible,

$0<\mathrm{R}_{\mathrm{L}}<1$-favorable sorption conditions,

$\mathrm{R}_{\mathrm{L}}=1$-linear nature of the sorption,

$\mathrm{R}_{\mathrm{L}}>1$ - unfavorable conditions for sorption.

The obtained data showed that the constant $R_{L}$ was always positive and lower than 1 , which indicates that the process of adsorption of the examined metal ions is favorable.

It can be concluded that the process of sorption of $\mathrm{Pb}$ (II) ions, $\mathrm{Cd}$ (II) ions and $\mathrm{Mn}$ (II) ions onto the spent coffee grounds is of a chemical nature, where the rate-limiting step is the rate of surface reactions.

Maximum sorption capacity for A-SCG was equal to $22.3 \mathrm{mg} / \mathrm{g}$, $19.6 \mathrm{mg} / \mathrm{g}$ and $19.4 \mathrm{mg} / \mathrm{g}$ for Pb(II) ions, $\mathrm{Cd}(\mathrm{II})$ ions and $\mathrm{Mn}(\mathrm{II})$ ions, respectively. These values where respectively $64 \%, 51 \%$ and $77 \%$ higher for A-SCG than for SCG.

\subsection{Kinetic Studies}

In order to find the physicochemical characteristics of the mechanism's process of sorption, the kinetics studies were performed. It seems that there are a couple steps in the adsorption process. The first stage is connected with the diffusion of metal ions on the surface of the sorbent and further into the pores. The next stage starts with the metal interaction with the sorbent active sites. In order to compare different kinetics models the correlation coefficient $\left(\mathrm{R}^{2}\right)$ was calculated. Three kinetic models were used such as the pseudo-first, pseudo-second and Webber-Morris model (Figure 7 and Tables 2-4). The solid lines show the second order linear fit and the dashed lines show the first order non-linear fit, which were the best fits to explain the adsorption of metal ions onto the SCG and A-SCG. In addition, 
the Chi-square test [26] was used to better compare the suitability of the model to the experimental results:

$$
\chi^{2}=\frac{\left(q_{\mathrm{e} e x p}-q_{\mathrm{e} \mathrm{cal}}\right)^{2}}{\mathrm{q}_{\mathrm{e} \text { cal }}}
$$

The last experimental point in each case was taken into account for calculating $\mathrm{q}_{\mathrm{e}}$ exp.

The linear pseudo first order model due to the high error in the $\chi^{2}$ and no adjustment to the experimental data was not the best fit for the described study. The non-linear pseudo first order model showed low error in the $\chi^{2}$, but low correlation coefficient $\mathrm{R}^{2}$. In addition, it assumed lower values at the last point $(60 \mathrm{~min})$ below the experimental data in each case, which can be clearly seen in the graphs, which might suggest that equilibrium was reached earlier. The non-linear pseudo second order model generally provides a larger $\chi^{2}$ error than the linear models and a lower correlation coefficient $\mathrm{R}^{2}$, but the obtained values and the presented graph were very close to that of the linear model [27]. The linear pseudo-second order had a slightly higher $\chi^{2}$ error than that in a linear method, but had a very high correlation coefficient $\mathrm{R}^{2}$ with satisfactory compliance with the experimental data. In this model, the values of $\mathrm{q}_{\mathrm{e}}$ al were in some cases higher than the last experimental point on the graph, mainly seen in A-SCG at initial concentrations over $150 \mathrm{mg} / \mathrm{dm}^{3}$. This suggests that the time of the experiment is not always sufficient to reach the equilibrium, but the extrapolation of the linear second-order plot can supply respective values.

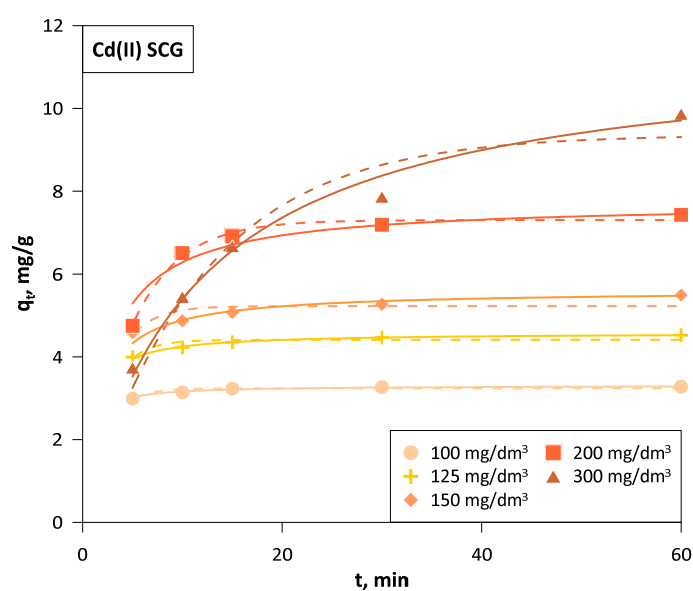

(a)

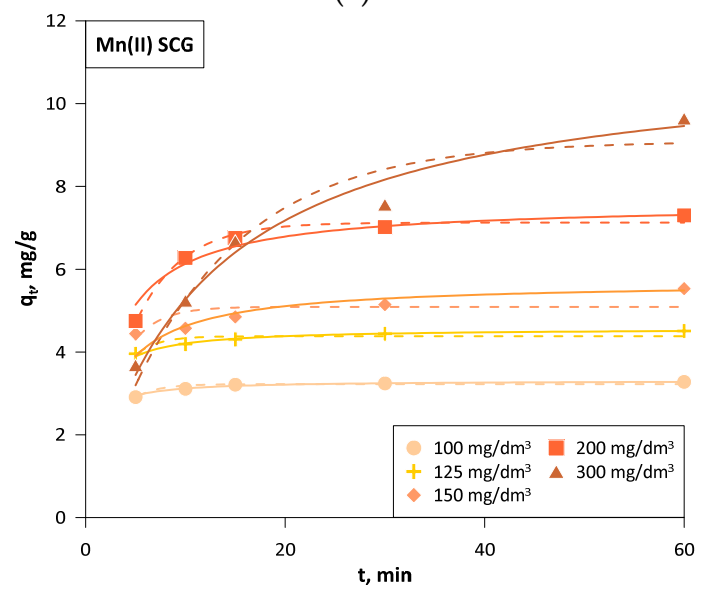

(c)

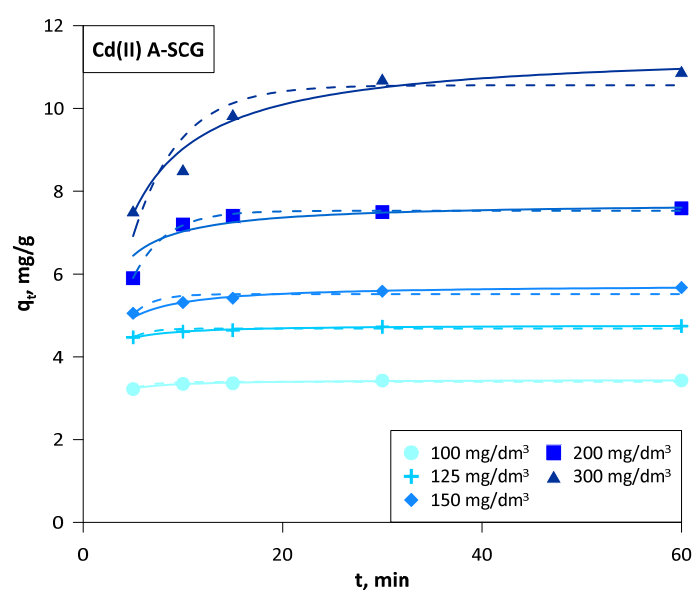

(b)

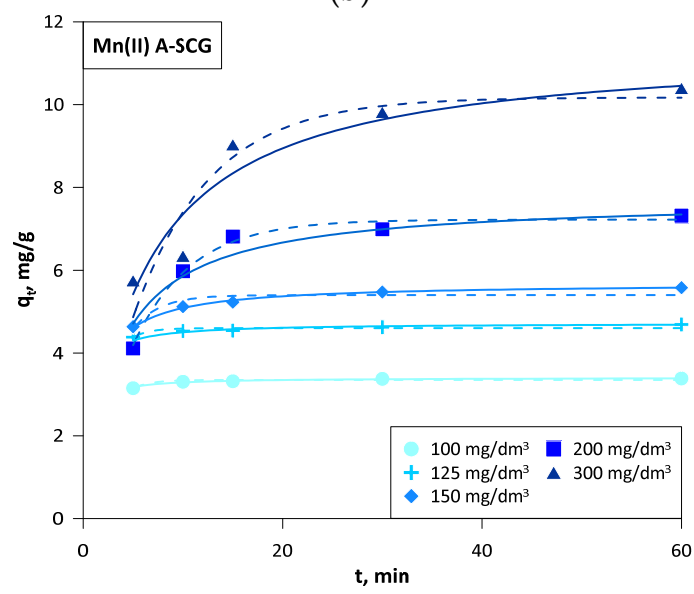

(d)

Figure 7. Cont. 


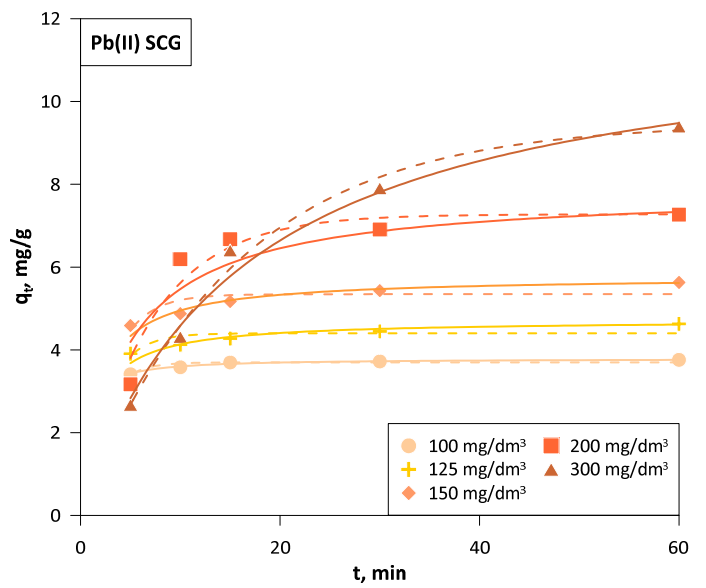

(e)

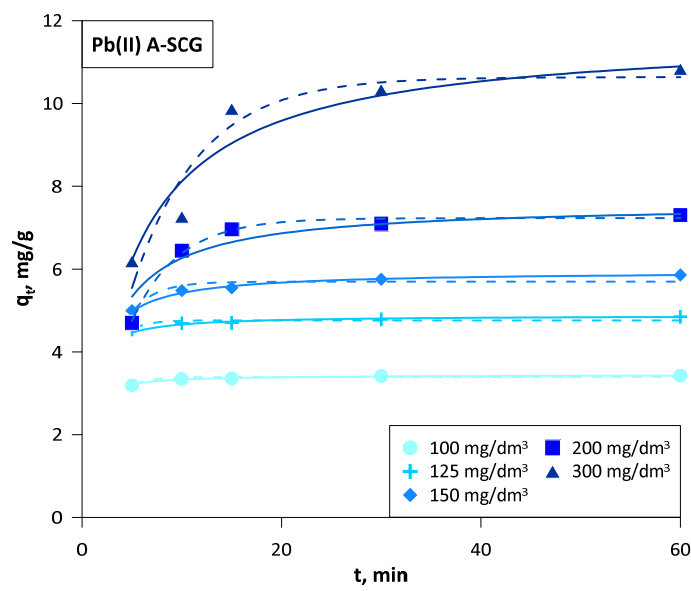

(f)

Figure 7. Kinetics of the linear pseudo-second order (solid lines) and non-linear pseudo-first order (dashed lines) models for A-SCG and SCG. (a) Cadmium, SCG; (b) Cadmium, A-SCG; (c) Manganese, SCG; (d) Manganese, A-SCG; (e) Lead, SCG; (f) Lead, A-SCG.

Table 2. Values of the parameters characterizing the Cd(II) sorption kinetics.

\begin{tabular}{|c|c|c|c|c|c|c|c|c|c|c|c|c|c|c|}
\hline \multirow[t]{2}{*}{$\begin{array}{c}\mathrm{C}_{\mathrm{o}}, \\
\mathrm{mg} / \mathrm{dm}^{3}\end{array}$} & \multirow[t]{2}{*}{$\begin{array}{l}\mathrm{q}_{\mathrm{e} \text { exp }} \\
\mathrm{mg} / \mathrm{g}\end{array}$} & \multicolumn{4}{|c|}{$\begin{array}{l}\text { Pseudo-First Order } \\
\text { (Non-linear) }\end{array}$} & \multicolumn{2}{|c|}{$\begin{array}{c}\text { Pseudo-Second } \\
\text { Order } \\
\text { (Non-linear) }\end{array}$} & \multicolumn{4}{|c|}{ Pseudo-Second Order (Linear) } & \multicolumn{3}{|c|}{ Webber-Morris } \\
\hline & & $\begin{array}{l}\text { qe cal, } \\
\mathrm{mg} / \mathrm{g}\end{array}$ & $\begin{array}{c}\mathbf{k}_{1} \\
1 / \mathrm{min}\end{array}$ & $x^{2}$ & $\mathbf{R}^{2}$ & $x^{2}$ & $\mathbf{R}^{2}$ & $\begin{array}{l}\mathrm{q}_{\text {e cal }} \\
\mathrm{mg} / \mathrm{g}\end{array}$ & $\begin{array}{c}\mathrm{k}_{2} \\
\mathrm{mg} / \mathrm{g} / \mathrm{min}\end{array}$ & $x^{2}$ & $\mathbf{R}^{2}$ & I & $\begin{array}{c}\mathrm{k}_{\mathrm{id}}{ }^{\prime} \\
\mathrm{mg} / \mathrm{g} \cdot \min ^{1 / 2}\end{array}$ & $\mathbf{R}^{2}$ \\
\hline \multicolumn{15}{|c|}{ Cd(II) SCG } \\
\hline 100 & 3.28 & 3.24 & 0.504 & 0.001 & 0.846 & 0.001 & 0.984 & 3.31 & 0.648 & 0.000 & 1.000 & 2.98 & 0.046 & 0.684 \\
\hline 125 & 4.52 & 4.41 & 0.456 & 0.003 & 0.784 & 0.000 & 0.994 & 4.58 & 0.275 & 0.001 & 1.000 & 3.92 & 0.088 & 0.807 \\
\hline 150 & 5.49 & 5.22 & 0.398 & 0.014 & 0.665 & 0.000 & 0.948 & 5.61 & 0.121 & 0.002 & 1.000 & 4.36 & 0.156 & 0.928 \\
\hline 200 & 7.43 & 7.30 & 0.212 & 0.002 & 0.991 & 0.036 & 0.938 & 7.74 & 0.056 & 0.012 & 0.999 & 4.79 & 0.393 & 0.638 \\
\hline 300 & 9.87 & 9.36 & 0.085 & 0.027 & 0.946 & 0.181 & 0.985 & 11.56 & 0.008 & 0.247 & 0.995 & 1.98 & 1.054 & 0.962 \\
\hline \multicolumn{15}{|c|}{ Cd(II) A-SCG } \\
\hline 100 & 3.43 & 3.40 & 0.589 & 0.000 & 0.832 & 0.000 & 0.984 & 3.45 & 0.883 & 0.000 & 1.000 & 3.21 & 0.033 & 0.715 \\
\hline 125 & 4.74 & 4.69 & 0.610 & 0.001 & 0.768 & 0.000 & 0.989 & 4.77 & 0.585 & 0.000 & 1.000 & 4.44 & 0.045 & 0.790 \\
\hline 150 & 5.67 & 5.52 & 0.482 & 0.004 & 0.726 & 0.000 & 0.981 & 5.75 & 0.216 & 0.001 & 1.000 & 4.94 & 0.104 & 0.862 \\
\hline 200 & 7.59 & 7.53 & 0.307 & 0.000 & 0.996 & 0.016 & 0.901 & 7.73 & 0.129 & 0.003 & 1.000 & 6.07 & 0.232 & 0.525 \\
\hline 300 & 10.91 & 10.56 & 0.213 & 0.011 & 0.857 & 0.033 & 0.963 & 11.45 & 0.033 & 0.025 & 0.999 & 6.81 & 0.600 & 0.805 \\
\hline
\end{tabular}

Table 3. Values of the parameters characterizing the Mn(II) sorption kinetics.

\begin{tabular}{|c|c|c|c|c|c|c|c|c|c|c|c|c|c|c|}
\hline \multirow[t]{2}{*}{$\begin{array}{c}\mathrm{C}_{\mathrm{o}} \\
\mathrm{mg} / \mathrm{dm}^{3}\end{array}$} & \multirow[t]{2}{*}{$\begin{array}{l}\text { qe exp } \\
\text { mg/g }\end{array}$} & \multicolumn{4}{|c|}{$\begin{array}{l}\text { Pseudo-First Order } \\
\text { (Non-linear) }\end{array}$} & \multicolumn{2}{|c|}{$\begin{array}{c}\text { Pseudo-Second } \\
\text { Order } \\
\text { (Non-linear) }\end{array}$} & \multicolumn{4}{|c|}{ Pseudo-Second Order (Linear) } & \multicolumn{3}{|c|}{ Webber-Morris } \\
\hline & & $\begin{array}{l}\text { qe cal, } \\
\mathrm{mg} / \mathrm{g}\end{array}$ & $\begin{array}{c}k_{1} \\
1 / \mathrm{min}\end{array}$ & $x^{2}$ & $\mathbf{R}^{2}$ & $x^{2}$ & $\mathbf{R}^{2}$ & $\begin{array}{l}\text { qe cal' } \\
\mathrm{mg} / \mathrm{g}\end{array}$ & $\begin{array}{c}\mathbf{k}_{2} \\
\mathrm{mg} / \mathrm{g} / \mathrm{min}\end{array}$ & $x^{2}$ & $\mathbf{R}^{2}$ & $\mathbf{I}$ & $\begin{array}{c}\mathrm{k}_{\mathrm{id}}{ }^{\prime} \\
\mathrm{mg} / \mathrm{g} \cdot \min ^{1 / 2}\end{array}$ & $\mathbf{R}^{2}$ \\
\hline \multicolumn{15}{|c|}{ Mn(II) SCG } \\
\hline 100 & 3.28 & 3.22 & 0.457 & 0.001 & 0.886 & 0.001 & 0.986 & 3.31 & 0.488 & 0.000 & 1.000 & 2.90 & 0.056 & 0.688 \\
\hline 125 & 4.51 & 4.38 & 0.453 & 0.004 & 0.753 & 0.000 & 0.988 & 4.57 & 0.251 & 0.001 & 1.000 & 3.87 & 0.092 & 0.840 \\
\hline 150 & 5.53 & 5.09 & 0.373 & 0.038 & 0.456 & 0.002 & 0.819 & 5.70 & 0.076 & 0.005 & 0.999 & 4.00 & 0.202 & 0.985 \\
\hline 200 & 7.30 & 7.13 & 0.215 & 0.004 & 0.987 & 0.028 & 0.961 & 7.60 & 0.055 & 0.012 & 1.000 & 4.69 & 0.384 & 0.683 \\
\hline 300 & 9.64 & 9.09 & 0.087 & 0.033 & 0.935 & 0.159 & 0.976 & 11.25 & 0.008 & 0.230 & 0.992 & 1.97 & 1.021 & 0.953 \\
\hline \multicolumn{15}{|c|}{ Mn(II) A-SCG } \\
\hline 100 & 3.39 & 3.35 & 0.560 & 0.000 & 0.889 & 0.000 & 0.979 & 3.41 & 0.827 & 0.000 & 1.000 & 3.15 & 0.036 & 0.673 \\
\hline 125 & 4.69 & 4.60 & 0.604 & 0.002 & 0.712 & 0.000 & 0.956 & 4.72 & 0.432 & 0.000 & 1.000 & 4.33 & 0.050 & 0.873 \\
\hline 150 & 5.58 & 5.40 & 0.376 & 0.006 & 0.839 & 0.001 & 0.995 & 5.69 & 0.149 & 0.002 & 1.000 & 4.52 & 0.153 & 0.802 \\
\hline 200 & 7.32 & 7.22 & 0.173 & 0.001 & 0.990 & 0.063 & 0.932 & 7.74 & 0.040 & 0.023 & 0.999 & 4.08 & 0.481 & 0.654 \\
\hline 300 & 10.40 & 10.17 & 0.130 & 0.005 & 0.882 & 0.113 & 0.908 & 11.42 & 0.016 & 0.091 & 0.995 & 4.39 & 0.863 & 0.797 \\
\hline
\end{tabular}


Table 4. Values of the parameters characterizing the $\mathrm{Pb}(\mathrm{II})$ sorption kinetics.

\begin{tabular}{|c|c|c|c|c|c|c|c|c|c|c|c|c|c|c|}
\hline \multirow[t]{2}{*}{$\begin{array}{c}\mathrm{C}_{\mathrm{o}} \\
\mathrm{mg} / \mathrm{dm}^{3}\end{array}$} & \multirow[t]{2}{*}{$\begin{array}{l}\text { qe expr } \\
\text { mg/g }\end{array}$} & \multicolumn{4}{|c|}{$\begin{array}{l}\text { Pseudo-First Order } \\
\text { (Non-linear) }\end{array}$} & \multicolumn{2}{|c|}{$\begin{array}{c}\text { Pseudo-Second } \\
\text { Order } \\
\text { (Non-linear) }\end{array}$} & \multicolumn{4}{|c|}{ Pseudo-Second Order (Linear) } & \multicolumn{3}{|c|}{ Webber-Morris } \\
\hline & & $\begin{array}{l}\text { qe cal, } \\
\mathrm{mg} / \mathrm{g}\end{array}$ & $\begin{array}{c}k_{1} \\
1 / \mathrm{min}\end{array}$ & $x^{2}$ & $\mathbf{R}^{2}$ & $x^{2}$ & $\mathbf{R}^{2}$ & $\begin{array}{l}\text { qe cal, } \\
\mathrm{mg} / \mathrm{g}\end{array}$ & $\begin{array}{c}\mathbf{k}_{2} \\
\mathrm{mg} / \mathrm{g} / \mathrm{min}\end{array}$ & $x^{2}$ & $\mathbf{R}^{2}$ & $\mathbf{I}$ & $\begin{array}{c}\mathrm{k}_{\mathrm{id}} \\
\mathrm{mg} / \mathrm{g} \cdot \min ^{1 / 2}\end{array}$ & $\mathbf{R}^{2}$ \\
\hline \multicolumn{15}{|c|}{$\mathrm{Pb}$ (II) SCG } \\
\hline 100 & 3.76 & 3.70 & 0.500 & 0.001 & 0.833 & 0.000 & 0.981 & 3.79 & 0.499 & 0.000 & 1.000 & 3.39 & 0.055 & 0.708 \\
\hline 125 & 4.63 & 4.40 & 0.416 & 0.012 & 0.634 & 0.000 & 0.936 & 4.72 & 0.149 & 0.002 & 1.000 & 3.72 & 0.125 & 0.941 \\
\hline 150 & 5.63 & 5.35 & 0.362 & 0.015 & 0.667 & 0.000 & 0.947 & 5.77 & 0.104 & 0.004 & 1.000 & 4.31 & 0.184 & 0.910 \\
\hline 200 & 7.27 & 7.28 & 0.148 & 0.000 & 0.923 & 0.121 & 0.839 & 7.87 & 0.029 & 0.046 & 0.992 & 3.47 & 0.572 & 0.561 \\
\hline 300 & 9.40 & 9.48 & 0.066 & 0.001 & 0.988 & 0.575 & 0.983 & 12.05 & 0.005 & 0.583 & 0.993 & 0.77 & 1.193 & 0.918 \\
\hline \multicolumn{15}{|c|}{$\mathrm{Pb}$ (II) A-SCG } \\
\hline 100 & 3.43 & 3.39 & 0.562 & 0.000 & 0.889 & 0.000 & 0.979 & 3.45 & 0.827 & 0.000 & 1.000 & 3.19 & 0.036 & 0.673 \\
\hline 125 & 4.85 & 4.76 & 0.612 & 0.002 & 0.713 & 0.000 & 0.956 & 4.88 & 0.437 & 0.000 & 1.000 & 4.49 & 0.049 & 0.871 \\
\hline 150 & 5.86 & 5.70 & 0.408 & 0.005 & 0.856 & 0.001 & 0.990 & 5.95 & 0.172 & 0.001 & 1.000 & 4.92 & 0.136 & 0.776 \\
\hline 200 & 7.31 & 7.23 & 0.214 & 0.001 & 0.994 & 0.040 & 0.917 & 7.59 & 0.062 & 0.010 & 0.999 & 4.81 & 0.376 & 0.595 \\
\hline 300 & 10.84 & 10.64 & 0.147 & 0.004 & 0.909 & 0.102 & 0.917 & 11.70 & 0.019 & 0.063 & 0.997 & 5.21 & 0.820 & 0.752 \\
\hline
\end{tabular}

Based on the kinetic data, it can be observed that for both the A-SCG and SCG and for all of the tested metal ions, the model with the best fit was the linear form of the pseudo-second order. The sorption equilibrium set in the early stage of the sorption process (on average $30 \mathrm{~min}$ for concentrations below $200 \mathrm{mg} / \mathrm{dm}^{3}$ ) for both used materials and all of the metal ions. The average sorption rate in the first $5 \mathrm{~min}$ at an initial concentration of $300 \mathrm{mg} / \mathrm{dm}^{3}$ was $1.51,1.15$ and $1.24 \mathrm{mg} / \mathrm{g} / \mathrm{min}$ for A-SCG, and this value was higher than 2.0, 1.6 and 2.3 times than for SCG for Cd(II), Mn(II) and $\mathrm{Pb}(\mathrm{II})$, respectively. Based on this information, it can be assumed that the process that limits the sorption of used metal ions is chemisorption, which is based on the influence of valence bonds through the sharing or exchange of electrons between ions and the sorbent.

\section{Conclusions}

The research showed that activated spent coffee grounds during the pyrolysis process in the fluidized bed reactor undergo substantial physical modification at the macroscopic and microscopic level. Thermal activation of SCG in the fluidized bed reactor not only improved sorption, but also provides a safe and stable sorbent that does not release organic substances into water solutions and can be easily separated from the mixture. A-SCG has the form of a porous biochar that can be used for the effective and rapid removal of metal ions from aqueous solutions.

The best model fit for the studied process was the Langmuir isotherm, and the pseudo-second order kinetic model correctly described the kinetics process. Thus, it can be concluded that the process of sorption of $\mathrm{Pb}$ (II) ions, $\mathrm{Cd}$ (II) ions and $\mathrm{Mn}$ (II) ions onto spent coffee grounds is of a chemical nature, where the rate-limiting step is the rate of the surface reactions.

Maximum sorption capacity derived from the Langmuir model for A-SCG was equal to $22.3 \mathrm{mg} / \mathrm{g}$, $19.6 \mathrm{mg} / \mathrm{g}$ and $19.4 \mathrm{mg} / \mathrm{g}$ for the $\mathrm{Pb}$ (II) ions, $\mathrm{Cd}(\mathrm{II})$ ions and $\mathrm{Mn}$ (II) ions, respectively. Furthermore, these values were respectively $64 \%, 51 \%$ and $77 \%$ higher for A-SCG than for SCG.

The sorption equilibrium set in the early stage of the sorption process (on average $30 \mathrm{~min}$ for concentrations below $200 \mathrm{mg} / \mathrm{dm}^{3}$ ) for both of the used materials and all of the metal ions. Kinetic models were calculated for both linear and non-linear forms and by further introduction of an additional statistical test, it was possible to obtain confirmation of reasonable fit with the experimental data.

Author Contributions: Conceptualization, methodology, J.C. and W.Ż.; investigation, data curation, J.C. and D.B., writing (original draft), J.C., writing (review and editing), J.C., D.B. and W.Ż. All authors have read and agreed to the published version of the manuscript.

Funding: This research received no external funding.

Conflicts of Interest: The authors declare no conflict of interest. 


\section{Symbols}

$\mathrm{C}_{\mathrm{o}} \quad$ initial concentration of metal ions $\left(\mathrm{mg} / \mathrm{dm}^{3}\right)$

$\mathrm{C}_{\mathrm{e}} \quad$ concentration of metal ions at equilibrium $\left(\mathrm{mg} / \mathrm{dm}^{3}\right)$

$\mathrm{q}_{\mathrm{e}} \quad$ sorption capacity at equilibrium $(\mathrm{mg} / \mathrm{g})$

$\mathrm{q}_{\mathrm{t}} \quad$ sorption capacity at any time $(\mathrm{mg} / \mathrm{g})$

$\mathrm{R}_{\mathrm{e}} \quad$ the percentage removal at equilibrium

$\mathrm{q}_{\max }$ maximum sorption capacity $(\mathrm{mg} / \mathrm{g})$

$\mathrm{K}_{\mathrm{L}} \quad$ Langmuir constant (L/mg)

$\mathrm{K}_{\mathrm{F}} \quad$ Freundlich constant $\left(\mathrm{mg}^{1-(1 / \mathrm{n})}\left(\mathrm{dm}^{3}\right)^{1 / \mathrm{n}^{-1}}\right)$

$\mathrm{n}$ heterogeneity factor

$\mathrm{K}_{\mathrm{T}}$ the equilibrium binding constant corresponding to the maximum binding energy $\left(\mathrm{dm}^{3} / \mathrm{g}\right)$

B constant related to the heat of sorption $(\mathrm{J} / \mathrm{mol})$

$b_{t} \quad$ Temkin isotherm constant

$\mathrm{k}_{1}$ the pseudo-first order rate constant (1/min)

$\mathrm{k}_{2} \quad$ the pseudo-second order rate constant $(\mathrm{g} /(\mathrm{mg} \cdot \mathrm{min}))$

$\mathrm{k}_{\mathrm{id}} \quad$ the intra-particle diffusion rate constant $\left(\mathrm{mg} / \mathrm{g} \cdot \mathrm{min}^{0.5}\right)$

I intercept of the line in Weber-Morris model

$\mathrm{q}_{\mathrm{e} \text { exp }}$ experimental amount of metal adsorbed at equilibrium $(\mathrm{mg} / \mathrm{g})$

qe cal calculated amount of metal adsorbed at equilibrium $(\mathrm{mg} / \mathrm{g})$

\section{References}

1. Klimmek, S.; Stan, H.J.; Wilke, A.; Bunke, G.; Buchholz, R. Comparative analysis of the biosorption of cadmium, lead, nickel, and zinc by algae. Environ. Sci. Technol. 2001, 35, 4283-4288. [CrossRef] [PubMed]

2. Reddad, Z.; Gérente, C.; Andrès, Y.; Thibault, J.F.; Le Cloirec, P. Cadmium and lead adsorption by a natural polysaccharide in MF membrane reactor: Experimental analysis and modelling. Water Res. 2003, 37, 3983-3991. [CrossRef]

3. Montazer-Rahmati, M.M.; Rabbani, P.; Abdolali, A.; Keshtkar, A.R. Kinetics and equilibrium studies on biosorption of cadmium, lead, and nickel ions from aqueous solutions by intact and chemically modified brown algae. J. Hazard. Mater. 2011, 185, 401-407. [CrossRef] [PubMed]

4. Mohan, D.; Pittman, C.U.; Bricka, M.; Smith, F.; Yancey, B.; Mohammad, J.; Steele, P.H.; Alexandre-Franco, M.F.; Gómez-Serrano, V.; Gong, H. Sorption of arsenic, cadmium, and lead by chars produced from fast pyrolysis of wood and bark during bio-oil production. J. Colloid Interface Sci. 2007, 310, 57-73. [CrossRef]

5. Bin Jusoh, A.; Cheng, W.H.; Low, W.M.; Nora'aini, A.; Megat Mohd Noor, M.J. Study on the removal of iron and manganese in groundwater by granular activated carbon. Desalination 2005, 182, 347-353. [CrossRef]

6. Pacini, V.A.; Ingallinella, A.M.; Sanguinetti, G. Removal of iron and manganese using biological roughing up flow filtration technology. Water Res. 2005, 39, 4463-4475. [CrossRef]

7. Marzal, P.; Seco, A.; Gabaldón, C.; Ferrer, J. Cadmium and zinc adsorption onto activated carbon: Influence of temperature, $\mathrm{pH}$ and metal/carbon ratio. J. Chem. Technol. Biotechnol. 1996, 66, 279-285. [CrossRef]

8. Pehlivan, E.; Gode, F. Batch sorption of divalent metal ions onto brown coal. Energy Sources, Part A Recover. Util. Environ. Eff. 2006, 28, 1493-1508. [CrossRef]

9. Pehlivan, E.; Altun, T.; Cetin, S.; Iqbal Bhanger, M. Lead sorption by waste biomass of hazelnut and almond shell. J. Hazard. Mater. 2009, 167, 1203-1208. [CrossRef]

10. Liu, Z.; Zhang, F.S. Removal of lead from water using biochars prepared from hydrothermal liquefaction of biomass. J. Hazard. Mater. 2009, 167, 933-939. [CrossRef]

11. Naeem, M.A.; Imran, M.; Amjad, M.; Abbas, G.; Tahir, M.; Murtaza, B.; Zakir, A.; Shahid, M.; Bulgariu, L.; Ahmad, I. Batch and column scale removal of cadmium from water using raw and acid activated wheat straw biochar. Water 2019, 11, 1438. [CrossRef]

12. Lucaci, A.R.; Bulgariu, D.; Ahmad, I.; Lisa, G.; Mocanu, A.M.; Bulgariu, L. Potential use of biochar from variouswaste biomass as biosorbent in Co(II) removal processes. Water 2019, 11, 1565. [CrossRef]

13. Inyang, M.I.; Gao, B.; Yao, Y.; Xue, Y.; Zimmerman, A.; Mosa, A.; Pullammanappallil, P.; Ok, Y.S.; Cao, X. A review of biochar as a low-cost adsorbent for aqueous heavy metal removal. Crit. Rev. Environ. Sci. Technol. 2016, 4, 406-433. [CrossRef] 
14. Le, P.K.T.; Vu, Q.T.H.; Nguyen, Q.T.V.; Tran, K.A.; Le, K.A. Spent coffee grounds as a valuable source of bioactive compounds and bioenergy. Chem. Eng. Trans. 2017, 56, 37-42. [CrossRef]

15. Plaza, M.G.; González, A.S.; Pevida, C.; Pis, J.J.; Rubiera, F. Valorisation of spent coffee grounds as $\mathrm{CO}_{2}$ adsorbents for postcombustion capture applications. Appl. Energy 2012, 99, 272-279. [CrossRef]

16. Cho, D.W.; Cho, S.H.; Song, H.; Kwon, E.E. Carbon dioxide assisted sustainability enhancement of pyrolysis of waste biomass: A case study with spent coffee ground. Bioresour. Technol. 2015, 189, 1-6. [CrossRef]

17. Tsai, W.T.; Liu, S.C.; Hsieh, C.H. Preparation and fuel properties of biochars from the pyrolysis of exhausted coffee residue. J. Anal. Appl. Pyrolysis. 2012, 93, 63-67. [CrossRef]

18. Kelkar, S.; Saffron, C.M.; Chai, L.; Bovee, J.; Stuecken, T.R.; Garedew, M.; Li, Z.; Kriegel, R.M. Pyrolysis of spent coffee grounds using a screw-conveyor reactor. Fuel Process. Technol. 2015, 137, 170-178. [CrossRef]

19. Bok, J.P.; Choi, H.S.; Choi, Y.S.; Park, H.C.; Kim, S.J. Fast pyrolysis of coffee grounds: Characteristics of product yields and biocrude oil quality. Energy 2012, 47, 17-24. [CrossRef]

20. Rybiński, P.; Żukowski, W.; Bradło, D. Effect of cenospheric fillers on the flammability and fire hazard of silicone rubber composites. J. Therm. Anal. Calorim. 2016, 125, 1373-1386. [CrossRef]

21. Yoon, S.Y.; Lee, C.G.; Park, J.A.; Kim, J.H.; Kim, S.B.; Lee, S.H.; Choi, J.W. Kinetic, equilibrium and thermodynamic studies for phosphate adsorption to magnetic iron oxide nanoparticles. Chem. Eng. J. 2014, 236, 341-347. [CrossRef]

22. Auta, M.; Hameed, B.H. Chitosan-clay composite as highly effective and low-cost adsorbent for batch and fixed-bed adsorption of methylene blue. Chem. Eng. J. 2014, 237, 352-361. [CrossRef]

23. Kaur, S.; Seema, R.; Mahajan, R.K.; Asif, M.; Gupta, V.K. Synthesis and adsorption properties of mesoporous material for the removal of dye safranin: kinetics, equilibrium, and thermodynamics. J. Ind. Eng. Chem. 2015, 22, 19-27. [CrossRef]

24. Dada, A.O.; Olalekan, A.P.; Olatunya, A.M.; Dada, O. Langmuir, freundlich, temkin and dubinin-radushkevich isotherms studies of equilibrium sorption of $\mathrm{Zn}^{2+}$ unto phosphoric acid modified rice husk. IOSR J. Appl. Chem. 2012, 3, 2278-5736. [CrossRef]

25. Yoosefian, M.; Ahmadzadeh, S.; Aghasi, M.; Dolatabadi, M. Optimization of electrocoagulation process for efficient removal of ciprofloxacin antibiotic using iron electrode; kinetic and isotherm studies of adsorption. J. Mol. Liq. 2017, 225, 544-553. [CrossRef]

26. Saleh, T.A.; Tuzen, M.; Sari, A. Magnetic activated carbon loaded with tungsten oxide nanoparticles for aluminum removal from waters. J. Environ. Chem. Eng. 2017, 5, 2853-2860. [CrossRef]

27. Markandeya, S.P.S.; Kisku, G.C. Linear and non-linear kinetic modeling for adsorption of disperse dye in batch process. Res. J. Environ. Toxicol. 2015, 9, 320-331. [CrossRef] 